Marquette University

e-Publications@Marquette

College of Nursing Faculty Research and

Publications

Nursing, College of

$3-2015$

\title{
Fluoxetine Prevents the Development of Depressive-like Behavior in a Mouse Model of Cancer Related Fatigue
}

\author{
Diana M. Norden \\ Ohio State University - Main Campus \\ Raymond Devine \\ Ohio State University - Main Campus \\ Sabahattin Bicer \\ Ohio State University - Main Campus \\ Runfeng Jing \\ Ohio State University - Main Campus \\ Peter J. Reiser \\ Ohio State University - Main Campus
}

See next page for additional authors

Follow this and additional works at: https://epublications.marquette.edu/nursing_fac

Part of the Nursing Commons

\section{Recommended Citation}

Norden, Diana M.; Devine, Raymond; Bicer, Sabahattin; Jing, Runfeng; Reiser, Peter J.; Wold, Loren E.; Godbout, Jonathan P.; and McCarthy, Donna O., "Fluoxetine Prevents the Development of Depressive-like Behavior in a Mouse Model of Cancer Related Fatigue" (2015). College of Nursing Faculty Research and Publications. 355.

https://epublications.marquette.edu/nursing_fac/355 


\section{Authors}

Diana M. Norden, Raymond Devine, Sabahattin Bicer, Runfeng Jing, Peter J. Reiser, Loren E. Wold, Jonathan P. Godbout, and Donna O. McCarthy 


\title{
Fluoxetine Prevents the Development of Depressive-like Behavior in a Mouse Model of Cancer Related Fatigue
}

\author{
Diana M. Norden \\ Department of Neuroscience, The Ohio State University, \\ Columbus, $\mathrm{OH}$ \\ Raymond Devine \\ Department of Physiology and Cell Biology, \\ The Ohio State University, \\ Columbus, $\mathrm{OH}$ \\ Sabahattin Bicer \\ Division of Biosciences, College of Dentistry, \\ The Ohio State University, \\ Columbus, $\mathrm{OH}$ \\ Runfeng Jing \\ College of Nursing, The Ohio State University, \\ Columbus, $\mathrm{OH}$ \\ Peter J. Reiser \\ Division of Biosciences, College of Dentistry, \\ The Ohio State University, \\ Columbus, $\mathrm{OH}$
}


NOT THE PUBLISHED VERSION; this is the author's final, peer-reviewed manuscript. The published version may be accessed by following the link in the citation at the bottom of the page.

\author{
Loren E. Wold \\ Department of Physiology and Cell Biology, \\ College of Nursing, The Ohio State University, \\ Columbus, $\mathrm{OH}$ \\ Jonathan P. Godbout \\ Department of Neuroscience, The Ohio State University, \\ Institute for Behavioral Medicine Research, \\ The Ohio State University, \\ Columbus, $\mathrm{OH}$ \\ Donna O. McCarthy \\ College of Nursing, Marquette University, \\ Milwaukee, WI
}

\begin{abstract}
Cancer patients frequently suffer from fatigue, a complex syndrome associated with tiredness and depressed mood. Cancer-related fatigue (CRF) can be present at the time of diagnosis, escalates during treatment, and can persist for years after treatment. CRF negatively influences quality of life, limits functional independence, and is associated with decreased survival in patients with incurable disease. We have previously shown that increased pro-inflammatory cytokine expression in the brain contributes to depressive- and fatigue- like behaviors in a mouse model of CRF. Inflammatory cytokines increase activity of indoleamine 2,3-dioxygenase (IDO) and kynurenine 3-monooxygenase (KMO), which competitively reduce serotonin synthesis. Reduced serotonin availability in the brain and increased production of alternative neuroactive metabolites of tryptophan are thought to contribute to the development of depression and fatigue. The purpose of this study was to determine the effects of fluoxetine, a selective serotonin reuptake inhibitor (SSRI), on brain cytokines and behavioral measures of fatigue and depression in tumor-bearing mice. Here we show that tumor growth increased brain expression of pro-inflammatory cytokines and KMO. Treatment with fluoxetine had no effect on tumor growth, muscle wasting, fatigue behavior, or cytokine expression in the brain. Fluoxetine, however, reduced depressive-like behaviors in tumor bearing mice. In conclusion, our data confirm that increased brain expression of pro-inflammatory cytokines is associated with tumor-induced fatigue and depressive-like behavior. However, it is possible to separate the effects of tumor growth on mood and fatigue-like behaviors using SSRI's such as fluoxetine.
\end{abstract}

Physiology \& Behavior, Vol 140 (March 1, 2015): pg. 230-235. DOI. This article is (C Elsevier and permission has been granted for this version to appear in e-Publications@Marquette. Elsevier does not grant permission for this article to be further copied/distributed or hosted elsewhere without the express permission from Elsevier. 
NOT THE PUBLISHED VERSION; this is the author's final, peer-reviewed manuscript. The published version may be accessed by following the link in the citation at the bottom of the page.

Keywords: fatigue, depression, cancer, neuroinflammation, serotonin, fluoxetine

\section{Introduction}

Cancer related fatigue (CRF) is the most common and most distressing symptom reported by cancer patients. CRF is characterized by overwhelming tiredness and lack of energy which significantly reduce quality of life. ${ }^{1}$ Importantly, fatigue is reported by cancer patients before and during treatment, and can continue for years after completion of treatment. ${ }^{2-4}$ In addition, CRF is frequently associated with depressed mood, ${ }^{5-7}$ although the mechanism for this association is unclear. A recent report ${ }^{8}$ suggests that pre-existing psychological conditions, such as depressed mood, increase the risk of persistent fatigue after completion of treatment. Others reported that treatment of cancer patients with antidepressant medications, such as selective serotonin reuptake inhibitors (SSRI), during chemotherapy improved mood but did not affect patient reports of fatigue. ${ }^{9,10}$ Others found that treatment with modafinil improved fatigue, but not depression, in cancer patients during chemotherapy. ${ }^{11}$

The association between symptoms of depression and fatigue in cancer patients suggests a common pathological pathway. Mounting evidence from both clinical and preclinical studies indicates that elevations in pro-inflammatory cytokines may function as a common mechanism for the frequent association of fatigue and depression in patients with CRF. For instance, elevated serum levels of proinflammatory cytokines, such as tumor necrosis factor-alpha (TNFa), interleukin (IL)- $1 \beta$ and IL-6, are associated with fatigue in cancer patients. ${ }^{12,13}$ Increases in systemic inflammation are relayed to the brain where inflammation is propagated by innate immune cells. ${ }^{14}$ Increased neuroinflammation, for example increased brain IL-1 $\beta$ expression, has been linked to both depressed mood ${ }^{15}$ and fatigue. ${ }^{16}$ Using a mouse model of CRF, we have previously shown that increased expression of pro-inflammatory cytokines within the CNS is associated with behavioral measures of fatigue, such as decreased voluntary wheel running (VWRA) activity, measures of weakness, such as reduced grip strength, and depressed mood, such as immobility during the forced swim test (FST) and anhedonia. ${ }^{17}$ Treatment with minocycline, a drug that reduces brain synthesis of inflammatory

Physiology \& Behavior, Vol 140 (March 1, 2015): pg. 230-235. DOI. This article is (C) Elsevier and permission has been granted for this version to appear in e-Publications@Marquette. Elsevier does not grant permission for this article to be further copied/distributed or hosted elsewhere without the express permission from Elsevier. 
cytokines, reduced depressive-like behaviors and improved grip strength in tumor-bearing mice. ${ }^{17}$

There are several proposed mechanisms by which increased neuroinflammation can lead to altered mood. Inflammatory cytokines increase expression and activity of the tryptophan degrading enzymes indoleamine 2,3-dioxygenase (IDO) and kynurenine 3-monooxygenase (KMO), which competitively inhibits activity of tryptophan hydroxylase (TPH) for metabolism of tryptophan to serotonin. Increased tryptophan metabolism by IDO into neuroactive metabolites leads to an imbalance in serotonin neurotransmission and subsequent development of depression. ${ }^{18,19}$ Inflammatory cytokines also increase expression and activity of the serotonin transporter. ${ }^{20}$ A recent study showed that peripheral tumors altered serotonin signaling pathways and decreased overall serotonin levels in the hypothalamus of tumor bearing mice. ${ }^{21}$ The purpose of the present study was to examine the effect of fluoxetine, a selective serotonin reuptake inhibitor (SSRI), on brain expression of pro-inflammatory cytokines and behaviors of fatigue and depressed mood in tumor bearing mice.

\section{Materials and methods}

\subsection{Mice}

Adult (10 weeks) female BALB/c $\times D B A / 2$ F1 (CD2F1) mice weighing 20-22 g were obtained from Charles River Laboratories. Female mice were used because we and others have shown that tumor-bearing females maintain their food intake longer and lose a smaller percent of body mass than male mice ${ }^{22}$ and male mice tend to gnaw and bite at the tumor site more than females, causing local inflammation. ${ }^{23}$ Mice were singly housed and maintained at $25^{\circ} \mathrm{C}$ under a $12 \mathrm{~h}$ light cycle with ad libitum access to water and rodent chow. All procedures were performed in accordance with the National Institute of Health Guidelines for the Care and Use of Laboratory Animals and were approved by The Ohio State University Institutional Animal Care and Use Committee.

Physiology \& Behavior, Vol 140 (March 1, 2015): pg. 230-235. DOI. This article is @ Elsevier and permission has been granted for this version to appear in e-Publications@Marquette. Elsevier does not grant permission for this article to be further copied/distributed or hosted elsewhere without the express permission from Elsevier. 
NOT THE PUBLISHED VERSION; this is the author's final, peer-reviewed manuscript. The published version may be accessed by following the link in the citation at the bottom of the page.

\subsection{Mouse model of tumor-growth}

The colon26 adenocarcinoma (colon26) cell line was maintained in culture and prepared for injection as previously described. ${ }^{24}$ Mice were injected subcutaneously between the scapulae with $5 \times 10^{5}$ cells in $0.2 \mathrm{ml}$ of PBS or PBS alone. This tumor cell line is syngeneic for CD2F1 mice and secretes IL-6 and TNF- $\mathrm{a}^{25}$ and does not metastasize when injected subcutaneously. ${ }^{26}$ Tumor growth is usually palpable by day 7; weight loss, splenomegaly, and muscle wasting are evident after day 14 , and mice become moribund by day 24 of tumor-growth. In the present study, all data collection was completed by day 21 of tumor growth. Body weight was monitored three times a week for the first two weeks, and daily during the third week. Mice were euthanized by inhalation of $\mathrm{CO}_{2}$ gas on day 21 of tumor growth. Gastrocnemius muscles, spleen, and tumor were dissected and weighed; the brain was quickly dissected and hippocampus brain tissue was snap frozen in liquid nitrogen. Carcass weight was determined by subtracting tumor weight from body weight at the time of sacrifice.

\subsection{Oral Fluoxetine administration}

Fluoxetine (Sigma, St. Louis) was administered in the drinking water at a dose of $3 \mathrm{mg} / \mathrm{kg} /$ day (Sigma, St. Louis) starting one day after injection of PBS or tumor cells. This dose of fluoxetine has previously been shown to block depressive-like behavior in mice without affecting locomotor activity of healthy mice. ${ }^{27}$ Water intake was monitored every other day. There was no difference between fluid intakes during the first two weeks of tumor growth. During week three, both tumor groups had increased water intake, but there was no difference between water and fluoxetine intake in the tumor animals. Water bottles were changed weekly throughout the study. Fluoxetine diluted in water has previously been shown to be stable for 8 weeks at room temperature. ${ }^{28}$

\subsection{Voluntary wheel running activity}

Fatigue-like behavior was determined using voluntary wheel running activity (VWRA). ${ }^{29}$ Mice were singly housed and acclimated to a four inch diameter running wheel in the cage for one week, and

Physiology \& Behavior, Vol 140 (March 1, 2015): pg. 230-235. DOI. This article is (C Elsevier and permission has been granted for this version to appear in e-Publications@Marquette. Elsevier does not grant permission for this article to be further copied/distributed or hosted elsewhere without the express permission from Elsevier. 
baseline measures (week 0) of VWRA were recorded overnight prior to injection with tumor cells or PBS. Wheels were again placed in the home cages of all mice overnight ( 6 p.m. to 8 a.m.) on days 8 (week 1), 14 (week 2) and 19 (week 3) of tumor growth and the total number of turns each night was digitally recorded (Columbus Instruments, model 0297-004M).

\subsection{Home cage locomotor activity}

Home cage locomotor activity test was performed between 4:30-6pm, before the beginning of the dark cycle when mice become more active and there is minimal disturbance in the vivarium. Mice were maintained in their home cage with a floor area of $26 \times 20 \mathrm{~cm}$, and activity was video recorded for 3 minutes. On the video records, cages were divided into 6 identical virtual rectangles and the number of line crossings was determined.

\subsection{Depressive-like behavior}

Depressive-like behavior was determined on day 13 using the forced swim test (FST) as described previously. ${ }^{30}$ The FST was performed following the home cage locomotor test between 4:30$6 \mathrm{pm}$. Mice were placed in an inescapable cylinder (diameter $16 \mathrm{~cm}$, height $30 \mathrm{~cm}$ ) containing $15 \mathrm{~cm}$ of water and behavior was recorded for five min. The latency to become immobile and the duration of immobility were determined.

\subsection{RNA isolation and RT-PCR analysis}

RNA was isolated from hippocampus brain sections using the Tri-Reagent protocol (Sigma) and reverse transcribed to CDNA using the High Capacity cDNA Reverse Transcription kit (Applied Biosystems). Quantitative PCR was performed using the Applied Biosystems Assay-on-Demand Gene Expression protocol. In brief, experimental cDNA was amplified with an ABI PRISM 7300-sequence detection system (Applied Biosystems) by real-time PCR and normalized based on reference cDNA (GAPDH). Data were analyzed with the comparative threshold cycle method. Data is expressed as fold change from control-vehicle.

Physiology \& Behavior, Vol 140 (March 1, 2015): pg. 230-235. DOI. This article is @ Elsevier and permission has been granted for this version to appear in e-Publications@Marquette. Elsevier does not grant permission for this article to be further copied/distributed or hosted elsewhere without the express permission from Elsevier. 
NOT THE PUBLISHED VERSION; this is the author's final, peer-reviewed manuscript. The published version may be accessed by following the link in the citation at the bottom of the page.

\subsection{Statistical Analysis}

Data were subjected to a Shapiro-Wilk test using Statistical Analysis Systems (SAS) software (Cary, NC). Observations greater than three interquartile ranges from the first and third quartile were considered outliers and were excluded in the subsequent analyses. To determine significant main effects and interactions between main factors, data were analyzed using one- or two- way ANOVA using the General Linear Model procedures of SAS. Differences between group means were evaluated with the $t$-test using the Least-Significant Difference procedure of SAS. All data are expressed as treatment means \pm standard error of the mean (SEM).

\section{Results}

\subsection{Effects of fluoxetine on tumor growth}

Mice were treated with water (vehicle) or fluoxetine at $3 \mathrm{mg} / \mathrm{kg} /$ day starting at one day after tumor cell inoculation to the completion of the study. In this model, tumor bearing mice lose significant muscle mass with the progression of tumor growth. Fig. 1A shows total body weight throughout the study. At the completion of the study (Day 21) tumor bearing mice had significantly decreased carcass weight compared to healthy control mice (Fig.1B) $\left(F_{1,52}=31.70, p<0.0001\right)$. There was no effect of fluoxetine on carcass weight. Associated with decreased carcass weight, gastrocnemius muscle mass was decreased in tumor-bearing mice compared to healthy controls $\left(F_{1,52}=147.86, p<0.0001\right)$ and was not altered by fluoxetine treatment (Fig.1C). Fluoxetine treatment had no effect on tumor mass (Fig.1D) or spleen weight, a nonspecific measure of systemic inflammation (Fig.1E). These data confirm that fluoxetine had no effects on tumor growth, weight loss, or loss of muscle mass in the tumor-bearing mice.

Physiology \& Behavior, Vol 140 (March 1, 2015): pg. 230-235. DOI. This article is (C Elsevier and permission has been granted for this version to appear in e-Publications@Marquette. Elsevier does not grant permission for this article to be further copied/distributed or hosted elsewhere without the express permission from Elsevier. 
A.

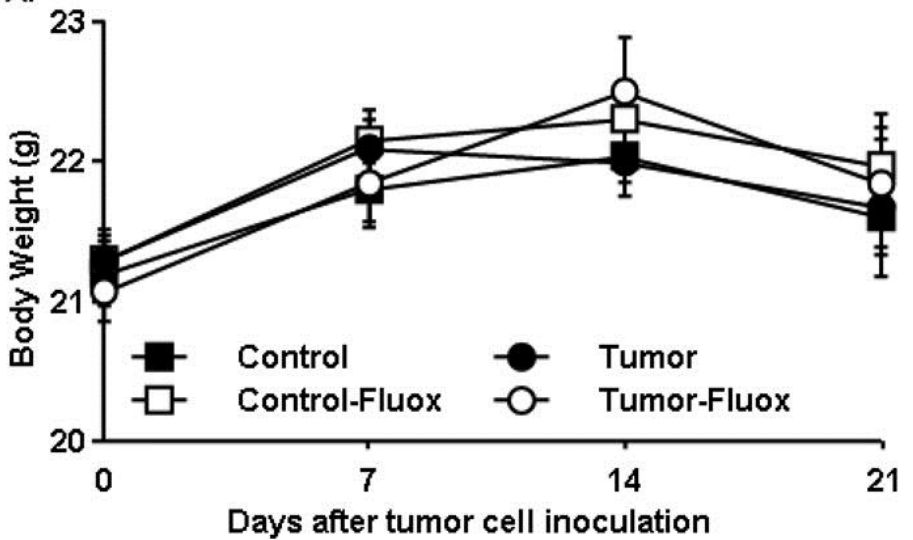

B.
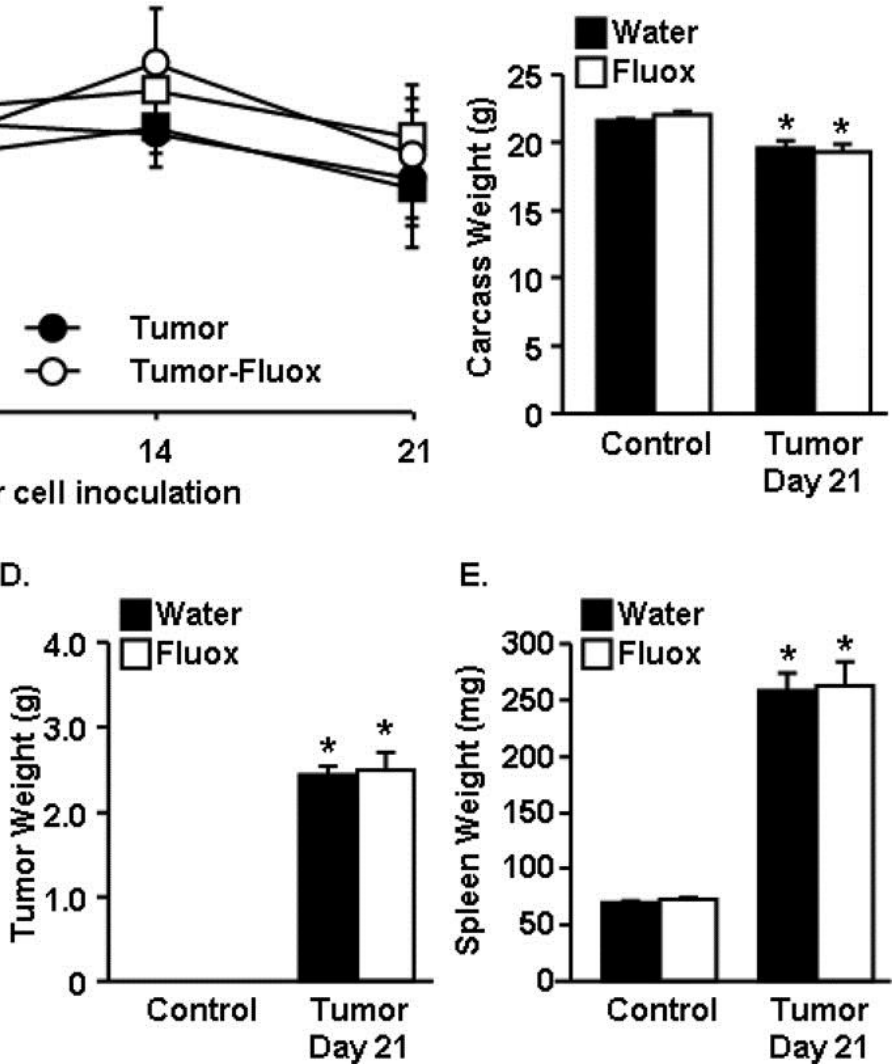

E.

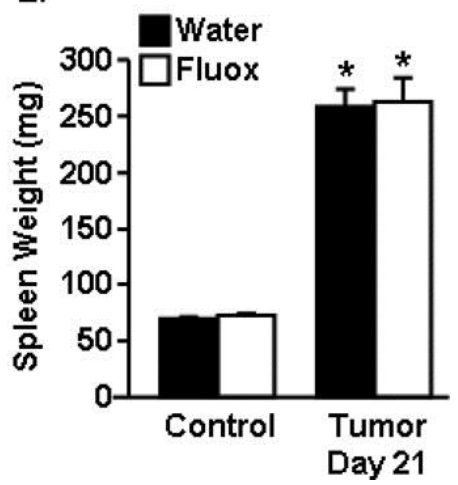

Figure 1. Fluoxetine had no effect on tumor growth Control and tumor-bearing mice were administered fluoxetine $(3 \mathrm{mg} / \mathrm{kg} / \mathrm{day})$ in the drinking water starting one day after tumor cell injection. A) Body weight was monitored through the study. At the completion of the study, B) carcass weight, C) gastrocnemius muscle mass, D) tumor mass, and E) spleen weight $(n=12)$ were analyzed using ANOVA. Means with $*$ are different from control mice $(p<0.05)$.

\subsection{Effects of fluoxetine on tumor-induced fatigue}

In this experiment, fatigue was modeled as a reduction in VWRA. ${ }^{29}$ VWRA progressively declined starting at day 14 in tumorbearing mice $\left(F_{1,38}=48.33, p<0.0001\right)$ and there was no effect of fluoxetine on VWRA (Fig.2). 


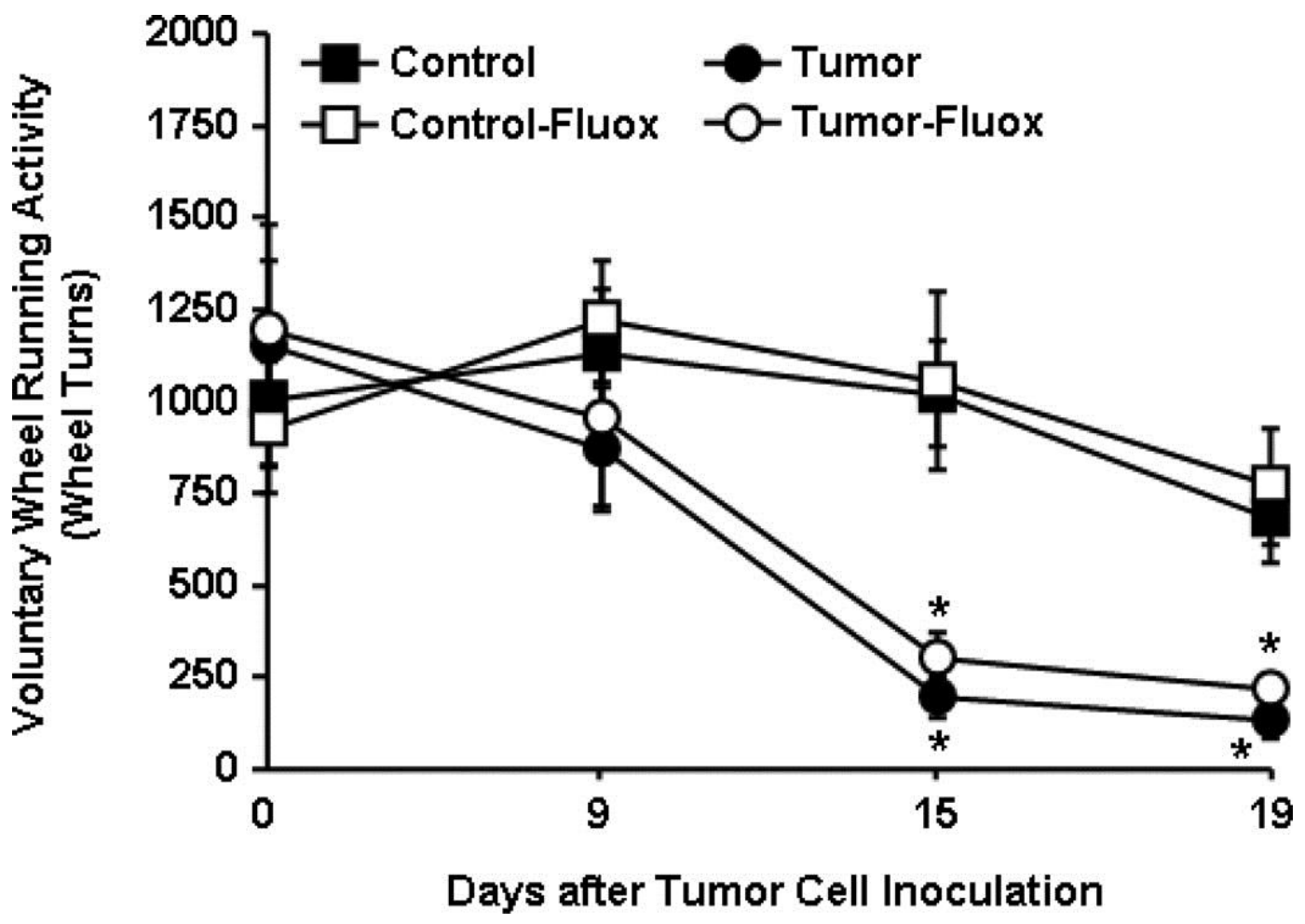

Figure 2. Fluoxetine had no effect on tumor-associated fatigue Control and tumor-bearing mice were administered fluoxetine $(3 \mathrm{mg} / \mathrm{kg} / \mathrm{day})$ in the drinking water starting one day after tumor cell injection. Voluntary wheel running activity (VWRA) was determined before tumor cell inoculation and again overnight on days 8,14 and $19(n=12)$. Data are expressed as mean \pm SEM and analyzed using ANOVA. Means with $*$ are different from control mice $(p<0.05)$.

\subsection{Effects of fluoxetine on tumor-induced depressive- like behavior}

Depressive-like behavior was determined at 13 days after tumor cell inoculation using the forced swim test (FST). Fig. 3A shows that home cage locomotor activity was not different between any of the groups, indicating that tumor bearing mice did not exhibit lethargy. Fig. 3B\&C show that tumor bearing mice became immobile sooner than healthy control mice $\left(F_{1,51}=11.66, p<0.0013\right)$, and had increased total time immobile in the FST $(p<0.01)$. Tumor bearing mice treated with fluoxetine, however, had decreased time to become immobile $\left(F_{1,51}=9.90, p<0.0029\right)$ and also decreased total time immobile $\left(F_{1,52}=6.48, p<0.014\right)$ compared to tumor mice that were not treated with fluoxetine. There were no significant differences between tumor bearing mice treated with fluoxetine and control mice. This dose of

Physiology \& Behavior, Vol 140 (March 1, 2015): pg. 230-235. DOI. This article is (C Elsevier and permission has been granted for this version to appear in e-Publications@Marquette. Elsevier does not grant permission for this article to be further copied/distributed or hosted elsewhere without the express permission from Elsevier. 
fluoxetine had no effect on locomotor activity or immobility during the FST in healthy control mice, as was reported by others. ${ }^{31}$

A.

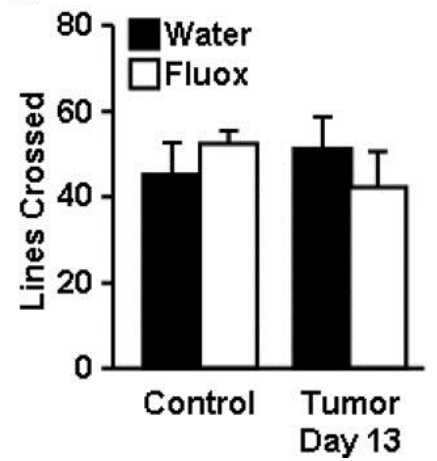

B.

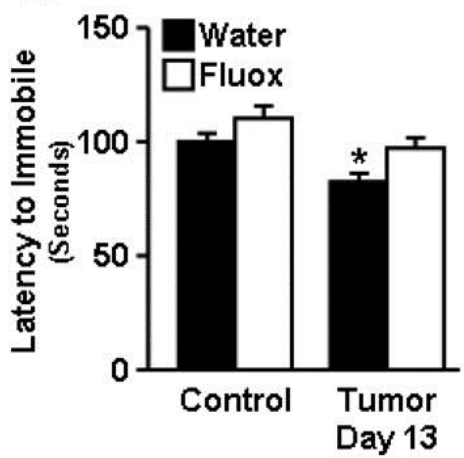

c.

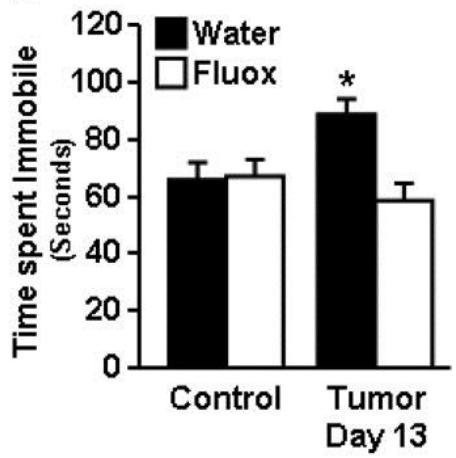

Figure 3. Fluoxetine inhibited depressive-like behavior in tumor bearing mice Control and tumor-bearing mice were administered fluoxetine in the drinking water starting one day after tumor cell injection. A) Home cage activity was determined 13 days after tumor inoculation. Control and tumor mice were exposed to the forced swim test (FST) at 13 days and B) latency to become immobile and C) total time immobile $(n=12)$ were analyzed using ANOVA. Bars represent the mean \pm SEM. Means with * are different from control $(p<0.05)$.

\subsection{Expression of brain cytokine mRNA}

In a previous report, we demonstrated that tumor growth increased IL-1 $\beta$ and IL- 6 mRNA expression in the hippocampus at 2 weeks of tumor growth and that expression levels were further increased by 3 weeks. ${ }^{17}$ In the present study, cytokine expression was determined in the hippocampus at day 21 (week 3). By 21 days of tumor growth, expression of IL-1 $\beta$ and IL- 6 was increased in tumor bearing mice compared to healthy controls (Fig.4A\&B) $\left(F_{1,27}=10.71\right.$, $p<0.003)$. Fluoxetine administration had no effect on IL-1 $\beta$ or IL-6 mRNA expression in the hippocampus. Fluoxetine, however, tended to reduce the expression of TNFa in both tumor-bearing and healthy control mice (Fig.4C) $\left(F_{1,28}=3.66, p=0.06\right)$. There was a tendency for $\mathrm{KMO}$ expression to be increased at 21 days of tumor growth $\left(F_{1,26}=2.59, p=0.1\right)$, and there was no effect of fluoxetine on $\mathrm{KMO}$ mRNA (Fig.4D). IDO expression was not altered with tumor growth or fluoxetine administration (data not shown). 
A.

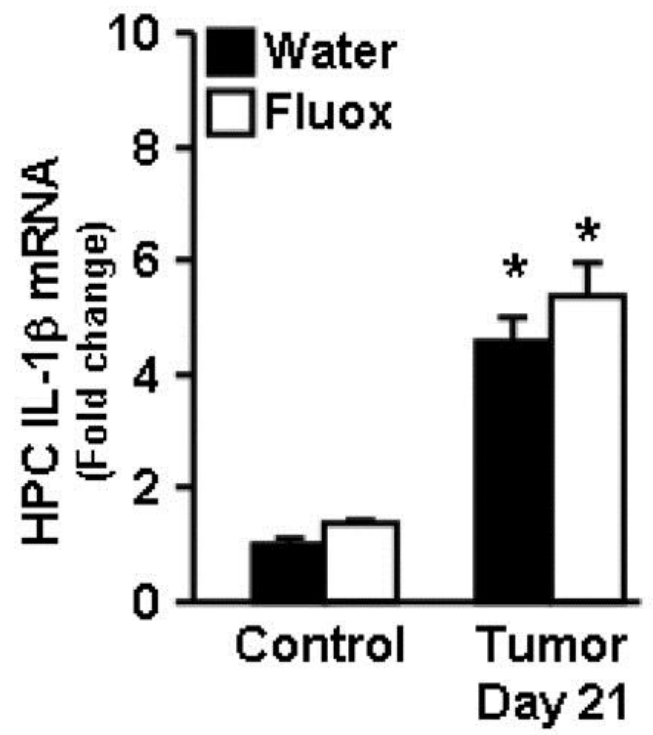

C.

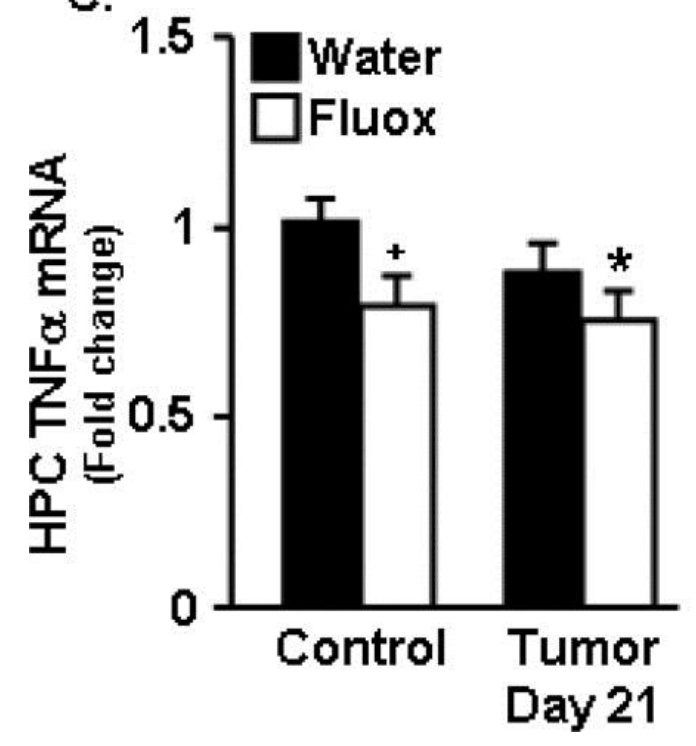

B.
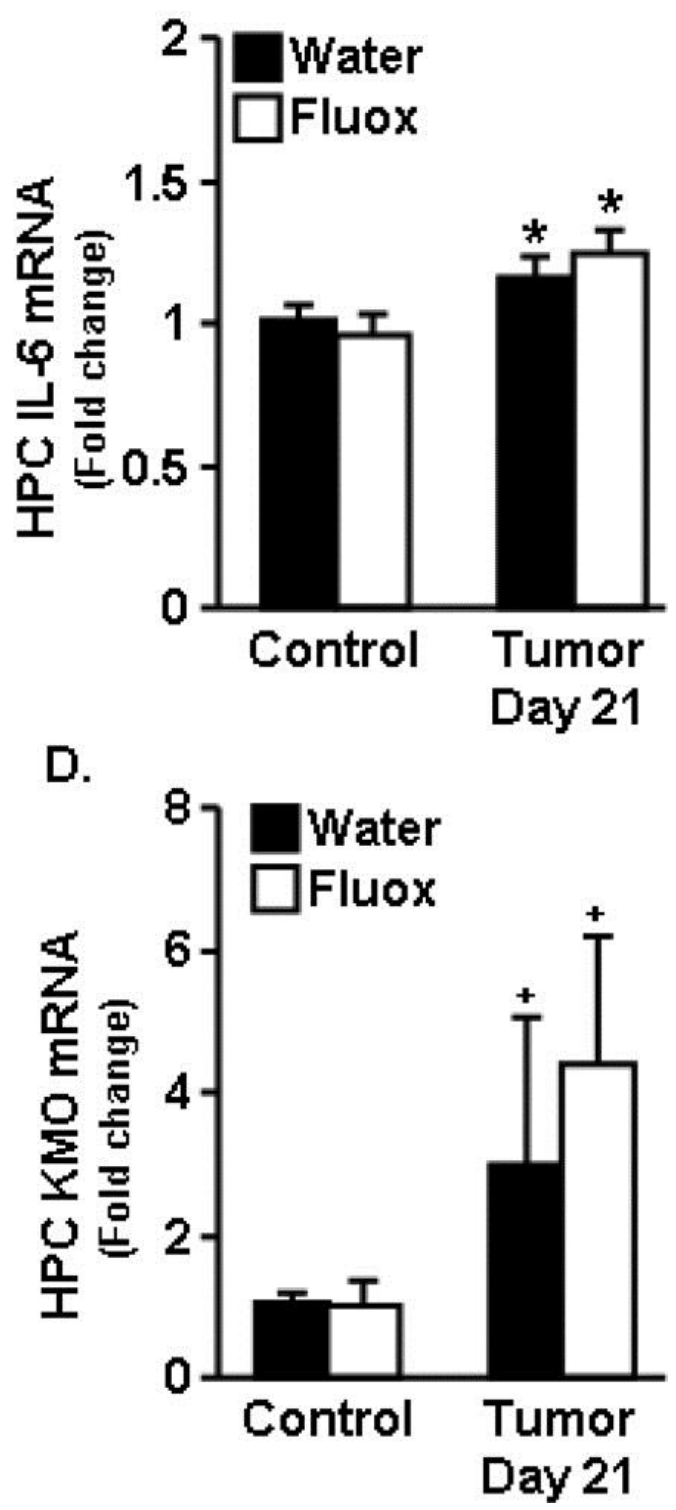

Figure 4. Fluoxetine had no effect on tumor-induced pro-inflammatory cytokine expression in the hippocampus

Control and tumor-bearing mice were administered fluoxetine $(3 \mathrm{mg} / \mathrm{kg} / \mathrm{day})$ in the drinking water. A-D) IL-1 $\beta$, IL-6, TNFa, and KMO mRNA expression was determined in the hippocampus at 21 days $(n=6-8)$. Data are expressed as mean $\pm S E M$ and were analyzed using ANOVA. Means with * are different from control mice $(p<0.05)$, means with + tend to be different from control mice $(p=0.1)$.

In conclusion, fluoxetine had no effect on tumor size, muscle mass, inflammatory cytokine expression in the brain, or fatigue behavior, but ameliorated depressive-like behavior in the tumorbearing mice. 
NOT THE PUBLISHED VERSION; this is the author's final, peer-reviewed manuscript. The published version may be accessed by following the link in the citation at the bottom of the page.

\section{Discussion}

Fatigue is a common and distressing symptom reported by cancer patients before, during, and after cancer treatments. Depressive symptoms are prevalent in patients with CRF and are associated with higher mortality rates in patients with persistent or incurable disease. ${ }^{32,} 33$ Therefore, treatments to reduce fatigue and depression in cancer patients are needed to increase quality of life and perhaps prolong survival. In this study, a mouse model of CRF was used to determine the effects of fluoxetine, a SSRI, on behavioral measures of depression and fatigue in tumor bearing mice. Here we report that tumor-bearing mice demonstrate fatigue (decreased VWRA) and depressed mood (increased immobility in FST) before weight loss is evident. We have previously shown that fatigue and depressive-like behavior in tumor-bearing mice is associated with increased expression of IL-1 $\beta$ and IL- 6 in the cortex and hippocampus, brain regions associated with mood and motor activity. ${ }^{17}$ Treatment of the tumor-bearing mice with fluoxetine did not affect tumor growth, body weight, muscle mass, or cytokine expression in the brain. However, fluoxetine reduced tumor-induced depressive-like behavior in tumor-bearing mice. These findings explain in part previous reports that treatment with an SSRI reduced depression, but did not reduce fatigue in cancer patients undergoing chemotherapy. ${ }^{9,} 10$

Reduced VWRA is used to model fatigue in rodents in response to immune challenge ${ }^{34}$ or chemotherapy. ${ }^{29}$ Consistent with our previous study, ${ }^{17}$ we show that VWRA progressively decreases in tumor bearing mice after day 14 of tumor growth with no change in home cage locomotor activity. These findings indicate that tumor growth did not cause general malaise or lethargy. Consistent with clinical findings, ${ }^{9,10}$ treatment with fluoxetine, a SSRI, did not affect fatigue behavior in tumor-bearing mice.

Depression often co-occurs with fatigue and is frequently reported by patients undergoing chemotherapy. ${ }^{7}$ In our mouse model of CRF, tumor-bearing mice demonstrated depressive-like behavior in the FST. We have previously shown that the increase in immobility in the FST is not due to changes in muscle function, lethargy, or malaise. ${ }^{17}$ Here we show that treatment with $3 / \mathrm{mg} / \mathrm{kg} /$ day fluoxetine

Physiology \& Behavior, Vol 140 (March 1, 2015): pg. 230-235. DOI. This article is @ Elsevier and permission has been granted for this version to appear in e-Publications@Marquette. Elsevier does not grant permission for this article to be further copied/distributed or hosted elsewhere without the express permission from Elsevier. 
was sufficient to ameliorate depressive-like behavior in tumor-bearing mice without changing mood-related behavior in healthy control mice. ${ }^{31}$ Fluoxetine treatment had no effect on muscle mass, VWRA, or home cage locomotor activity in tumor-bearing mice. These data suggest the effects of fluoxetine were specific to tumor-induced depressive-like behavior in these mice.

The underlying mechanisms of CRF are unknown but may be related to a heightened inflammatory state. ${ }^{2}$ In rodent models of inflammation and immune activation, elevated IL-1 $\beta$ expression in the brain has been associated with fatigue and depression. ${ }^{16,} 30$ The results of the present study support the hypothesis that tumor growth induces neuroinflammation, which negatively affects mood which may play a major role in the association of fatigue and depression in cancer patients. ${ }^{4-6,35,36}$

Previous studies have shown anti-inflammatory effects of fluoxetine on neuroinflammation. For example, fluoxetine decreased TNFa and IL-1 $\beta$ expression in a rat model of stroke. ${ }^{37}$ In our study, we show that peripheral inflammation (spleen weight) was not affected by fluoxetine treatment, nor was brain expression of IL- $1 \beta$ and IL- 6 mRNA. As shown in our previous study ${ }^{17}$ growth of this tumor did not increase brain expression of TNFa mRNA; however, fluoxetine reduced TNFa expression in the brain of both tumor-bearing and control mice. Previous studies has shown that $5 \mathrm{mg} / \mathrm{kg}$ fluoxetine treatment decreased plasma TNFa in mice injected with lipopolysaccharide ${ }^{38}$ and reduced TNFa expression in immune activated microglia and monocyte cell lines. ${ }^{39}$ It is possible that TNFa is a specific regulatory target of fluoxetine treatment. It is also possible that administration of a higher dose of fluoxetine may alter pro-inflammatory cytokine expression in the brain. However, high doses of fluoxetine alter locomotor activity which might confound our measures of home cage activity and VWRA in the treated animals. ${ }^{27}$ Therefore we chose to use a relatively low dose of fluoxetine in the present study. Overall, the reduced depressive-like behavior in tumor bearing mice treated with fluoxetine was not due to reduced expression of IL-1 $\beta$, IL-6, IDO or KMO mRNA in the brain of treated mice. We hypothesize that fluoxetine enhanced serotonin activity in the brain without changing tumor-induced neuroinflammation.

Physiology \& Behavior, Vol 140 (March 1, 2015): pg. 230-235. DOI. This article is $\subset$ Elsevier and permission has been granted for this version to appear in e-Publications@Marquette. Elsevier does not grant permission for this article to be further copied/distributed or hosted elsewhere without the express permission from Elsevier. 
NOT THE PUBLISHED VERSION; this is the author's final, peer-reviewed manuscript. The published version may be accessed by following the link in the citation at the bottom of the page.

Peripheral and CNS inflammation are also thought to induce depressive-like behavior via increased activity of IDO and KMO, which may reduce serotonin synthesis in the brain. Because proinflammatory cytokines can increase expression and activity of the IDO enzyme ${ }^{40}$ and serotonin transporter, ${ }^{20}$ we suggest a link between increased pro-inflammatory cytokines and decreased serotonin availability in the tumor bearing mice. We and others have shown that inhibiting IDO activity decreases serotonin turnover in the brain. ${ }^{40-42}$ As an SSRI, fluoxetine treatment reduces serotonin reuptake into the presynaptic cell, which increases extracellular levels of serotonin in the synaptic cleft that is available to bind to the postsynaptic receptor.

Tryptophan is the limiting factor for the synthesis of serotonin, therefore, increased activity of IDO may alter serotonin availability and turnover. In this study we show novel data that KMO expression was greater in tumor-bearing mice than in control mice, which suggests that tryptophan is shunted into the IDO and KMO-mediated pathway of tryptophan metabolism. Previous studies showed that peripheral tumor progression decreased serotonin levels in the hypothalamus of tumor bearing mice. ${ }^{21,43}$ Therefore, it is likely that altered serotonin availability contributes to depressed mood associated with tumor growth. Prior reports that SSRIs reduce depression in cancer patients, ${ }^{9,10}$ and our finding that fluoxetine inhibited depression-like behavior in tumor bearing mice support this hypothesis. Further research using methods such as microdialysis to determine free serotonin in the cerebrospinal fluid of treated versus untreated tumorbearing mice is needed to confirm this hypothesis. Other explanations for the beneficial effects of fluoxetine include improved neuronal plasticity and neurogenesis. Recent studies using rodent models have shown that neurogenesis is decreased in the hippocampus of tumor bearing mice. ${ }^{23}$ In a model of chemotherapy, fluoxetine treatment increased hippocampal neurogenesis and rescued memory impairments induced by the chemotherapy treatment. ${ }^{44}$ Further research is needed to determine if fluoxetine affected hippocampal neurogenesis in our study, which may have played a role in reducing depressive-like behaviors.

In conclusion, we show that a low dose $(3 \mathrm{mg} / \mathrm{kg} /$ day) of fluoxetine administration is sufficient to reduce depressive-like behaviors in tumor-bearing mice without altering other physiological

Physiology \& Behavior, Vol 140 (March 1, 2015): pg. 230-235. DOI. This article is @ Elsevier and permission has been granted for this version to appear in e-Publications@Marquette. Elsevier does not grant permission for this article to be further copied/distributed or hosted elsewhere without the express permission from Elsevier. 
effects of tumor growth. Consistent with clinical studies, fluoxetine had no effect on tumor-induced fatigue behaviors in this animal model of CRF. These data suggest that fatigue and depression associated with CRF may be treated as two distinct symptoms.

\section{Highlights}

Tumor growth increased brain expression of pro-inflammatory cytokines.

Fluoxetine had no effect on cytokine expression in tumor bearing mice.

Fluoxetine reduced depressive-like behaviors but not fatigue in tumor bearing mice.

\section{Acknowledgements}

This work was supported by NIH grant R01-NR-012618 to DOM, LEW, and PJR.

\section{Footnotes}

Publisher's Disclaimer: This is a PDF file of an unedited manuscript that has been accepted for publication. As a service to our customers we are providing this early version of the manuscript. The manuscript will undergo copyediting, typesetting, and review of the resulting proof before it is published in its final citable form. Please note that during the production process errors may be discovered which could affect the content, and all legal disclaimers that apply to the journal pertain.

\section{References}

${ }^{1}$ Berger AM, Abernethy AP, Atkinson A, Barsevick AM, Breitbart WS, Cella D, Cimprich B, Cleeland C, Eisenberger MA, Escalante CP, et al. Cancerrelated fatigue. Journal of the National Comprehensive Cancer Network : JNCCN. 2010;8:904-931.

2 Bower JE, Lamkin DM. Inflammation and cancer-related fatigue: mechanisms, contributing factors, and treatment implications. Brain, Behavior, and Immunity. 2013;30(Suppl):S48-S57.

${ }^{3}$ Husson O, Nieuwlaat WA, Oranje WA, Haak HR, van de Poll-Franse LV, Mols F. Fatigue Among Short- and Long-Term Thyroid Cancer Survivors: Results from the Population-Based PROFILES Registry. Thyroid. 2013;23:1247-1255.

Physiology \& Behavior, Vol 140 (March 1, 2015): pg. 230-235. DOI. This article is @ Elsevier and permission has been granted for this version to appear in e-Publications@Marquette. Elsevier does not grant permission for this article to be further copied/distributed or hosted elsewhere without the express permission from Elsevier. 
NOT THE PUBLISHED VERSION; this is the author's final, peer-reviewed manuscript. The published version may be accessed by following the link in the citation at the bottom of the page.

${ }^{4}$ Minton O, Alexander S, Stone PC. Identification of factors associated with cancer related fatigue syndrome in disease-free breast cancer patients after completing primary treatment. Breast Cancer Research and Treatment. 2012;136:513-520.

${ }^{5}$ Bower JE, Ganz PA, Irwin MR, Kwan L, Breen EC, Cole SW. Inflammation and behavioral symptoms after breast cancer treatment: do fatigue, depression, and sleep disturbance share a common underlying mechanism? Journal of Clinical Oncology. 2011;29:3517-3522.

${ }^{6}$ Kim HJ, Barsevick AM, Fang CY, Miaskowski C. Common biological pathways underlying the psychoneurological symptom cluster in cancer patients. Cancer Nursing. 2012;35:E1-E20.

7 Pertl MM, Hevey D, Boyle NT, Hughes MM, Collier S, O'Dwyer AM, Harkin A, Kennedy MJ, Connor TJ. C-reactive protein predicts fatigue independently of depression in breast cancer patients prior to chemotherapy. Brain, Behavior, and Immunity. 2013;34:108-119.

${ }^{8}$ Schmidt ME, Chang-Claude J, Seibold P, Vrieling A, Heinz J, Flesch-Janys D, Steindorf K. Determinants of long-term fatigue in breast cancer survivors: results of a prospective patient cohort study. Psychooncology. 2014

9 Morrow GR, Hickok JT, Roscoe JA, Raubertas RF, Andrews PL, Flynn PJ, Hynes HE, Banerjee TK, Kirshner JJ, King DK. Differential effects of paroxetine on fatigue and depression: a randomized, double-blind trial from the University of Rochester Cancer Center Community Clinical Oncology Program. Journal of Clinical Oncology. 2003;21:4635-4641.

10 Roscoe JA, Morrow GR, Hickok JT, Mustian KM, Griggs JJ, Matteson SE, Bushunow P, Qazi R, Smith B. Effect of paroxetine hydrochloride (Paxil) on fatigue and depression in breast cancer patients receiving chemotherapy. Breast Cancer Research and Treatment. 2005;89:243249.

11 Jean-Pierre $P$, Morrow GR, Roscoe JA, Heckler C, Mohile S, Janelsins M, Peppone L, Hemstad A, Esparaz BT, Hopkins JO. A phase 3 randomized, placebo-controlled, doubleblind, clinical trial of the effect of modafinil on cancer-related fatigue among 631 patients receiving chemotherapy: a University of Rochester Cancer Center Community Clinical Oncology Program Research base study. Cancer. 2010;116:3513-3520.

12 Saligan LN, Kim HS. A systematic review of the association between immunogenomic markers and cancer-related fatigue. Brain, Behavior, and Immunity. 2012;26:830-848.

13 Wood LJ, Weymann K. Inflammation and neural signaling: etiologic mechanisms of the cancer treatment-related symptom cluster. Current Opinion in Supportive and Palliative Care. 2013;7:54-59.

Physiology \& Behavior, Vol 140 (March 1, 2015): pg. 230-235. DOI. This article is (C Elsevier and permission has been granted for this version to appear in e-Publications@Marquette. Elsevier does not grant permission for this article to be further copied/distributed or hosted elsewhere without the express permission from Elsevier 
NOT THE PUBLISHED VERSION; this is the author's final, peer-reviewed manuscript. The published version may be

accessed by following the link in the citation at the bottom of the page.

${ }^{14}$ Henry CJ, Huang Y, Wynne A, Hanke M, Himler J, Bailey MT, Sheridan JF, Godbout JP. Minocycline attenuates lipopolysaccharide (LPS)-induced neuroinflammation, sickness behavior, and anhedonia. Journal of Neuroinflammation. 2008;5:15.

15 Haroon E, Raison CL, Miller AH. Psychoneuroimmunology meets neuropsychopharmacology: translational implications of the impact of inflammation on behavior. Neuropsychopharmacology. 2012;37:137162.

${ }^{16}$ Carmichael MD, Davis JM, Murphy EA, Brown AS, Carson JA, Mayer EP, Ghaffar A. Role of brain IL-1beta on fatigue after exercise-induced muscle damage. American Journal of Physiology Regulatory, Integrative and Comparative Physiology. 2006;291:R1344-R1348.

17 Norden DM, Bicer S, Clark Y, Jing R, Henry CJ, Wold LE, Reiser PJ, Godbout JP, McCarthy DO. Tumor growth increases neuroinflammation, fatigue and depressive-like behavior prior to alterations in muscle function. Brain, Behavior, and Immunity. 2015;43:76-85.

18 Raison CL, Dantzer R, Kelley KW, Lawson MA, Woolwine BJ, Vogt G, Spivey JR, Saito K, Miller AH. CSF concentrations of brain tryptophan and kynurenines during immune stimulation with IFN-alpha: relationship to CNS immune responses and depression. Molecular Psychiatry. 2010;15:393-403.

19 Dantzer R, O'Connor JC, Lawson MA, Kelley KW. Inflammation-associated depression: from serotonin to kynurenine. Psychoneuroendocrinology. $2011 ; 36: 426-436$.

20 Haase J, Brown E. Integrating the monoamine, neurotrophin and cytokine hypotheses of depression - A central role for the serotonin transporter? Pharmacology \& Therapeutics. 2014

${ }^{21}$ Dwarkasing JT, van Dijk M, Dijk FJ, Boekschoten MV, Faber J, Argiles JM, Laviano A, Muller M, Witkamp RF, van Norren K. Hypothalamic food intake regulation in a cancercachectic mouse model. Journal of Cachexia, Sarcopenia and Muscle. 2014;5:159-169.

${ }^{22}$ Cosper PF, Leinwand LA. Cancer causes cardiac atrophy and autophagy in a sexually dimorphic manner. Cancer Research. 2011;71:1710-1720.

23 Yang M, Kim J, Kim J-S, Kim S-H, Kim J-C, Kang M-J, Jung U, Shin T, Wang $\mathrm{H}$, Moon C. Hippocampal dysfunctions in tumor-bearing mice. Brain, Behavior, and Immunity. 2014;36:147-155.

${ }^{24}$ Xu H, Crawford D, Hutchinson KR, Youtz DJ, Lucchesi PA, Velten M, McCarthy DO, Wold LE. Myocardial dysfunction in an animal model of cancer cachexia. Life Sciences. 2011;88:406-410.

25 Graves E, Ramsay E, McCarthy DO. Inhibitors of COX activity preserve muscle mass in mice bearing the Lewis lung carcinoma, but not the B16 melanoma. Research in Nursing \& Health. 2006;29:87-97.

Physiology \& Behavior, Vol 140 (March 1, 2015): pg. 230-235. DOI. This article is @ Elsevier and permission has been granted for this version to appear in e-Publications@Marquette. Elsevier does not grant permission for this article to be further copied/distributed or hosted elsewhere without the express permission from Elsevier. 
${ }^{26}$ Okayama T, Kokura S, Ishikawa T, Adachi S, Hattori T, Takagi T, Handa O, Naito $Y$, Yoshikawa T. Antitumor effect of pretreatment for colon cancer cells with hyperthermia plus geranylgeranylacetone in experimental metastasis models and a subcutaneous tumor model of colon cancer in mice. International Journal of Hyperthermia. 2009;25:141-149.

27 Weber M, Talmon S, Schulze I, Boeddinghaus C, Gross G, Schoemaker H, Wicke KM. Running wheel activity is sensitive to acute treatment with selective inhibitors for either serotonin or norepinephrine reuptake. Psychopharmacology. 2009;203:753-762.

28 Peterson JA, Risley DS, Anderson PN, Hostettler KF. Stability of fluoxetine hydrochloride in fluoxetine solution diluted with common pharmaceutical diluents. American Journal of Hospital Pharmacy. $1994 ; 51: 1342-1345$.

${ }^{29}$ Zombeck JA, Fey EG, Lyng GD, Sonis ST. A clinically translatable mouse model for chemotherapy-related fatigue. Comparative Medicine. 2013;63:491-497.

${ }^{30}$ Godbout JP, Moreau M, Lestage J, Chen J, Sparkman NL, J OC, Castanon N, Kelley KW, Dantzer R, Johnson RW. Aging exacerbates depressive-like behavior in mice in response to activation of the peripheral innate immune system. Neuropsychopharmacology. 2008;33:2341-2351.

${ }^{31}$ Dulawa SC, Holick KA, Gundersen B, Hen R. Effects of chronic fluoxetine in animal models of anxiety and depression. Neuropsychopharmacology. 2004;29:1321-1330.

32 Mols F, Husson O, Roukema JA, van de Poll-Franse LV. Depressive symptoms are a risk factor for all-cause mortality: results from a prospective population-based study among 3,080 cancer survivors from the PROFILES registry. Journal of Cancer Survivorship : Research and Practice. 2013;7:484-492.

33 Brown LF, Kroenke K. Cancer-related fatigue and its associations with depression and anxiety: a systematic review. Psychosomatics. 2009;50:440-447.

${ }^{34}$ Hopwood N, Maswanganyi T, Harden LM. Comparison of anorexia, lethargy, and fever induced by bacterial and viral mimetics in rats. Canadian Journal of Physiology and Pharmacology. 2009;87:211-220.

35 Kirkova J, Aktas A, Walsh D, Davis MP. Cancer symptom clusters: clinical and research methodology. Journal of Palliative Medicine. 2011;14:1149-1166.

${ }^{36}$ Phillips SM, McAuley E. Physical activity and fatigue in breast cancer survivors: a panel model examining the role of self-efficacy and depression. Cancer Epidemiology, Biomarkers \& Prevention. $2013 ; 22: 773-781$.

Physiology \& Behavior, Vol 140 (March 1, 2015): pg. 230-235. DOI. This article is @ Elsevier and permission has been granted for this version to appear in e-Publications@Marquette. Elsevier does not grant permission for this article to be further copied/distributed or hosted elsewhere without the express permission from Elsevier. 
37 Lim CM, Kim SW, Park JY, Kim C, Yoon SH, Lee JK. Fluoxetine affords robust neuroprotection in the postischemic brain via its antiinflammatory effect. Journal of Neuroscience Research. 2009;87:1037-1045.

38 Roumestan C, Michel A, Bichon F, Portet K, Detoc M, Henriquet C, Jaffuel D, Mathieu M. Anti-inflammatory properties of desipramine and fluoxetine. Respiratory Research. 2007;8:35.

39 Liu D, Wang Z, Liu S, Wang F, Zhao S, Hao A. Anti-inflammatory effects of fluoxetine in lipopolysaccharide(LPS)-stimulated microglial cells. Neuropharmacology. 2011;61:592-599.

${ }^{40}$ Kim H, Chen L, Lim G, Sung B, Wang S, McCabe MF, Rusanescu G, Yang L, Tian $Y$, Mao J. Brain indoleamine 2,3-dioxygenase contributes to the comorbidity of pain and depression. The Journal of Clinical Investigation. 2012;122:2940-2954.

${ }^{41}$ Corona AW, Norden DM, Skendelas JP, Huang Y, O'Connor JC, Lawson M, Dantzer R, Kelley KW, Godbout JP. Indoleamine 2,3-dioxygenase inhibition attenuates lipopolysaccharide induced persistent microglial activation and depressive-like complications in fractalkine receptor (CX(3)CR1)-deficient mice. Brain, Behavior, and Immunity. 2013;31:134-142.

42 Muller N, Schwarz MJ. The immune-mediated alteration of serotonin and glutamate: towards an integrated view of depression. Molecular Psychiatry. 2007;12:988-1000.

43 Uomoto M, Nishibori M, Nakaya N, Takeuchi Y, Iwagaki H, Tanaka N, Saeki $\mathrm{K}$. Changes in monoamine turnover in the brain of cachectic mice bearing colon-26 tumor cells. Journal of Neurochemistry. 1998;70:260-267.

44 Lyons L, ElBeltagy M, Umka J, Markwick R, Startin C, Bennett G, Wigmore $P$. Fluoxetine reverses the memory impairment and reduction in proliferation and survival of hippocampal cells caused by methotrexate chemotherapy. Psychopharmacology. 2011;215:105-115.

To whom correspondence should be addressed: Donna McCarthy, 235 Clark Hall, Marquette University, P.O. Box 1881, Milwaukee WI, 53202-1881, Tel: 414-288-3820, Email: donnalee.mccarthy@marquette.edu. 